\title{
Plumericin inhibits growth of liver carcinoma cells via downregulation of COX-2 and VEGF
}

\author{
Jie Min ${ }^{1}$, Lili Cao ${ }^{2}$, Jun Zhou ${ }^{1}$, Xiaojun $\mathrm{Wu}^{1}$, Liang $\mathrm{Li}^{1 *}$ \\ ${ }^{1}$ Department of Hepatobiliary Surgery, The First Hospital of Jiaxing, The First Affiliated Hospital of Jiaxing University, \\ ${ }^{2}$ Department of Surgery, The Third Hospital of Jiaxing, Jiaxing-314001, China
}

*For correspondence: Email: I113666762783@hotmail.com; Tel: +86 57382082937

\begin{abstract}
Purpose: To investigate the antitumor effect of plumericin on hepatocellular carcinoma and the underlying molecular mechanism(s).

Methods: Invasion of cancer cells was measured with matrigel Transwell assay, while COX 2 and VEGF mRNA expressions were determined using quantitative polymerase chain reaction ( $q P C R$ )

Results: Plumericin caused dose-dependent reductions in proliferations of Hep 3B and Hep G2 cancer cells. The degrees of proliferation of Hep $3 B$ cells were 91, 84, 72, 57, 42 and $29 \%$ at plumericin concentrations of $5,10,15,20,25$ and $30 \mu \mathrm{M}$, respectively. In Hep G2 cells plumericin treatment at doses of $5,10,15,20,25$ and $30 \mu \mathrm{M}$ decreased proliferation to 89, 78, 64, 53, 42 and $30 \%$, respectively at $72 \mathrm{~h}$. Treatment of Hep $3 \mathrm{~B}$ cells at plumericin doses of 20,25 and $30 \mu \mathrm{M}$ led to induction of apoptosis in $41.23,56.76$ and $68.54 \%$ of cells, respectively after $72 \mathrm{~h}$. Plumericin suppressed the invasion potential of Hep $3 B$ cells in a dose-dependent manner. Compared to control, the proportion of Hep $3 B$ cells in G2/M phase of cell cycle increased significantly at doses of 20, 25 and $30 \mu M$. Plumericin treatment of Hep 3B cells led to significant decrease in expressions of COX 2 and VEGF. Conclusion: Plumericin suppresses liver cancer cell growth in vitro and in vivo by inhibition of COX 2 and VEGF expressions. Thus, it may be used for the treatment of liver cancer.
\end{abstract}

Keywords: Metastasis, Aflatoxins, Plumericin, Matrigel, Cyclooxygenase

\begin{abstract}
This is an Open Access article that uses a funding model which does not charge readers or their institutions for access and distributed under the terms of the Creative Commons Attribution License (http://creativecommons.org/licenses/by/4.0) and the Budapest Open Access Initiative (http://www.budapestopenaccessinitiative.org/read), which permit unrestricted use, distribution, and reproduction in any medium, provided the original work is properly credited.

Tropical Journal of Pharmaceutical Research is indexed by Science Citation Index (SciSearch), Scopus, International Pharmaceutical Abstract, Chemical Abstracts, Embase, Index Copernicus, EBSCO, African Index Medicus, JournalSeek, Journal Citation Reports/Science Edition, Directory of Open Access Journals (DOAJ), African Journal Online, Bioline International, Open-J-Gate and Pharmacy Abstracts
\end{abstract}

\section{INTRODUCTION}

Hepatocellular carcinoma (HCC), also known as primary liver cancer is the third leading cause of death due to cancer throughout the world, and it affects 600.000 people every year [1,2]. In most of the cases, traditional chemotherapy has been found to be ineffective [3]. It has been reported that HCC is one of the most resistant types of the carcinomas, with respect to chemotherapy and radiotherapy [4]. It metastasizes easily to the lymph nodes, pulmonary tissues, bones, adrenal glands and skull [4].

Although surgical intervention has been found to increase the 5-year survival in some patients, the results are not satisfactory in majority of cases [5]. Thus, research on the discovery and development of new therapeutic strategy for the $\mathrm{HCC}$ is of immense importance. Hepatocellular 
carcinoma (HCC) arises from ingestion of aflatoxins, nitrosoamines, alcohol addiction, hepatitis and chronic liver diseases [6]. Chronic hepatitis leading to cirrhosis is responsible for high incidence of HCC in China [7-9]. Natural products obtained from plant origin have been found to be very effective in the treatment of cancer [10]. Some natural products exhibit their effects through induction of apoptosis and cell cycle arrest, and also by synergizing with phosphatidylinositol 3-kinase $[11,12]$.

Traditional Chinese Medicine in combination with modern chemotherapy has been reported to yield some satisfactory results in HCC treatment [13]. Traditional Chinese Medicine is preferred for carcinoma treatment because the active ingredients directly inhibit the growth and proliferation of cancer cells [14-17], and improve the immune system [18].

The present study investigated the effect of plumericin on proliferation and invasive potential of liver cancer cells in vitro, and its effect on the growth of liver tumor in vivo. The effect of plumericin on the expressions of COX-2 and VEGF was also investigated.

\section{EXPERIMENTAL}

\section{Cell culture}

The Hep 3B and Hep G2 liver cancer cells were obtained from the Cell Bank of the Chinese Academy of Sciences (Shanghai, China). The cells were cultured in RPMI-1640 (Gibco; Thermo Fisher Scientific, Inc.) medium containing $10 \%$ fetal bovine serum (PBS, Gibco; Thermo Fisher Scientific, Inc.) at $37{ }^{\circ} \mathrm{C}$ in an atmosphere containing $5 \% \mathrm{CO}_{2}$.

\section{MTT assay} The Hep 3B and Hep G2 cells were seeded intoBiosciences, Franklin Lakes, NJ, USA) for the 96-well plates pre-coated with agarose $(0.6 \%)$ at adata analysis.

density of $2 \times 10^{5}$ cells/well in RPMI- 1640 medium.

After overnight incubation, plumericin at doses of 5,Assay of COX-2 and VEGF expressions $10,15,20,25$ and $30 \mu \mathrm{M}$ was added to different

wells of the plate, and the plates were incubated atHep 3B cells were treated for $72 \mathrm{~h}$ with plumericin $37{ }^{\circ} \mathrm{C}$ for $72 \mathrm{~h}$. Following incubation, the mediumat doses of 20,25 and $30 \mu \mathrm{M}$, with untreated was removed from the plates and the cells werecells as control. The cells were then collected for incubated for $4 \mathrm{~h}$ with $20 \mu \mathrm{L}$ MTT solution $(5 \mathrm{mg} / \mathrm{mLextraction}$ of total RNA using TRIzol reagent in PBS). Then, DMSO $(150 \mu \mathrm{L})$ was added to each(Invitrogen Life Technologies, Carlsbad, CA, well to solubilize the resultant formazan crystals,USA). The template for cDNA was constructed for and the absorbances of the solutions were read atperforming $\mathrm{QPCR}$ with specific primers for 570-nm in an enzyme-labeling instrument (ELx800cyclooxygenase-2, vascular endothelial growth Absorbance Microplate Reader type, BioTekfactor and $\beta$-actin. Micro-capillary tube Instruments, Inc., Winooski, VT, USA).
Apoptosis induction in Hep $3 \mathrm{~B}$ cells was rmined with flow cytometry using Annexin V/FITC kit (BD Biosciences, San Jose, CA, USA) provided in the user manual. The Hep 3B cells were incubated for $72 \mathrm{~h}$ with 20,25 and $30 \mu \mathrm{M}$ plumericin, harvested, and exposed to HEPES at room temperature for $20 \mathrm{~min}$. The cells were then subjected to flow cytometric analysis in a FACSCanto ${ }^{\text {TM }}$ flow cytometer (BD Biosciences).

\section{Cell invasion assays}

Invasion of Hep 3B cells through matrigel basement membrane (Sigma-Adrich, Carlsbad, , USA) was determined using the procedure were plated onto matrigel-coated transwell inserts (BD Biosciences) and treated with plumericin at

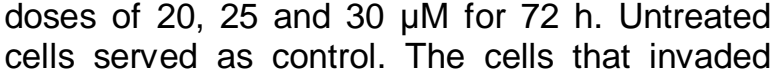
HEMA staining, counted and subsequently

\section{Cell cycle analysis}

Hep 3B cells were distributed into 6-well plates $2.5 \times 10^{5}$ cells/well) and incubated with Untreated cells were used as control. Then the cells were subjected to trypsinization, washed in subsequently fixed in $70 \%$ ethanol. The fixed cells were stained with $\mathrm{PI}(0.5 \mathrm{mg} / \mathrm{mL})$ in PBS and RNase A $(50 \mathrm{mg} / \mathrm{mL})$. Flow cytometric analysis was performed using flow cytometer. ModiFit LTTM software version 4.0 (BD employing a Light CyclerTM (Roche Diagnostics, Basel, Switzerland) in combination with SYBR $\AA$ Green Tag ReadyMix ${ }^{\mathrm{TM}}$ (Sigma-Aldrich) was propidium iodide (PI) (BD) method. Annexin through matrigel-coated inserts were subjected to 
used for qPCR assays for transcriptions of cyclooxygenase-2 and vascular endothelial growth factor. The reaction mixture in the microcapillary tube contained nuclease-free water (7.1 $\mu \mathrm{L})$, SYBR reagent $(10 \mu \mathrm{L})$, template cDNA $(0.5$ $\mu \mathrm{L})$, magnesium chloride (1.6 $\mu \mathrm{L} ; 25 \mathrm{mM})$, and primer mixture $(0.8 \mu \mathrm{L} ; 25 \mathrm{pmol} / \mu \mathrm{L})$. The conditions used for cycling were as follows: 30 sec denaturation at $95^{\circ} \mathrm{C}, 5 \mathrm{sec}$ annealing at 55 ${ }^{\circ} \mathrm{C}, 25 \mathrm{sec}$ extension at $72{ }^{\circ} \mathrm{C}$ and $1 \mathrm{sec}$ detection at $80{ }^{\circ} \mathrm{C}$ over 30 cycles. The products of PCR were subjected to electrophoresis using agarose gel $(2.0 \%)$ and photographed under UV.

\section{Animals and treatment}

A total of twenty BALB/c male mice (4-weeks-old) were purchased from the Beijing (HFK Bioscience Co., Ltd). The mice were kept in plastic cages under $12 \mathrm{~h}$ light/dark cycles, $25^{\circ} \mathrm{C}$ temperature and $48 \%$ humidity. The animals were provided food and water ad libitum. The mice, after oneweek of acclimatization to laboratory atmosphere, were assigned to four groups of 5 mice each. Hep $3 \mathrm{~B}$ cells $\left(2.5 \times 10^{6}\right)$ were injected subcutaneously into the mice belonging to untreated (control), 25 and $30 \mathrm{mg} / \mathrm{kg}$ treatment groups. At day 7 of injection, mice in the two treatment groups were given 25 or $30 \mathrm{mg} / \mathrm{kg}$ of plumericin daily up to one month of Hep 3B cell administration. The animals in the untreated and normal control groups received normal saline alone. After one month, the mice were sacrificed under isoflurane anaesthesia, and the tumor tissues were excised. The animal experimental protocols used in this study were approved by the Laboratory Animal Committee of the China Medical University (approval no. 20164351) and conducted according to the guidelines of "Principles of Laboratory Animal Care" (NIH publication no. 8523, revised 1985).

\section{Statistical analysis}

Data are expressed as mean \pm standard deviation (SD, $n=3)$. Statistical analysis of data was performed by one-way analysis of variance (ANOVA) with the SPSS software, version 11.5 (SPSS, Inc., Chicago, IL, USA). Differences were taken as significant statistically at $p<0.05$.

\section{RESULTS}

\section{Plumericin inhibited the proliferation of Hep 3B and Hep G2 liver cancer cells}

Plumericin caused dose-dependent reduction in proliferation of Hep 3B and Hep G2 cancer cells. The degrees of proliferation were $91,84,72,57$, 42 and $29 \%$ at plumericin doses of $5,10,15,20$,
25 and $30 \mu \mathrm{M}$, respectively, in Hep 3B cells (Figure 1). In Hep G2 cells, plumericin treatment at doses of $5,10,15,20,25$ and $30 \mu \mathrm{M}$ decreased proliferation to $89,78,64,53,42$ and $30 \%$, respectively after $72 \mathrm{~h}$ (Figure 1 ).

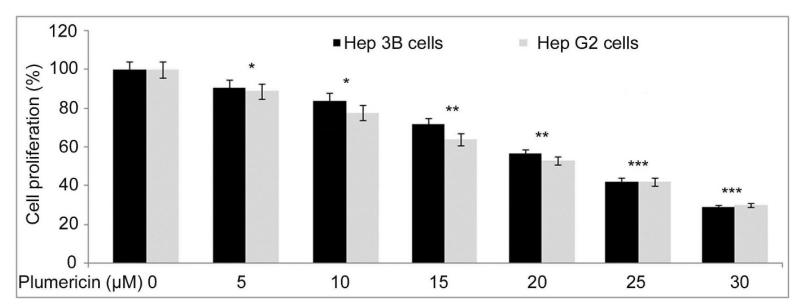

Figure 1: Effect of plumericin on the proliferation of Hep 3B and Hep G2 cancer cells. The cells, after $72 \mathrm{~h}$ of incubation with $5,10,15,20,25$ and $30 \mu \mathrm{M}$ plumericin, were subjected to MTT assay. Data are presented are mean \pm standard deviation of triplicate experiments. ${ }^{*} p<0.05,{ }^{* \star} p<0.02$ and ${ }^{* \star *} p<0.02$, compared to control cells

\section{Plumericin induced apoptosis in Hep 3B cells}

Treatment of Hep 3B cells with plumericin at doses of 20,25 and $30 \mu \mathrm{M}$ to induction of apoptosis in $41.23,56.76$ and $68.54 \%$ of cells, respectively after $72 \mathrm{~h}$ (Figure 2). The percentage of apoptotic cells in untreated control cultures of Hep 3B cells was $1.76 \%$ (Figure 2).
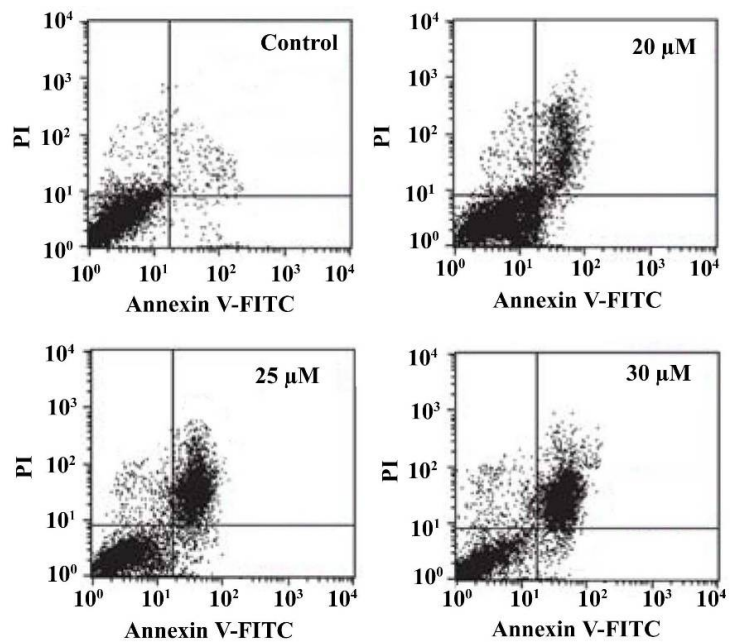

Figure 2: Effect of plumericin on apoptosis in Hep 3B cells. The cell cultures were incubated with plumericin at doses of 20,25 and $30 \mu \mathrm{M}$ for $72 \mathrm{~h}$, and then subjected to flow cytometry using Annexin V-fluorescein isothiocyanate (FITC) and propidium iodide (PI)

\section{Plumericin inhibited invasion of Hep 3B cells}

Hep 3B cells were incubated with plumericin at doses of 20,25 and $30 \mu \mathrm{M}$, and their invasion potential were determined using the Transwell chamber assay. It was found that plumericin treatment led to suppression of invasion potential 
of Hep 3B cells in a dose-dependent manner (Figure 3). The suppression of Hep 3B cell invasion potential was significant at all the three tested doses of plumericin (Figure 3).

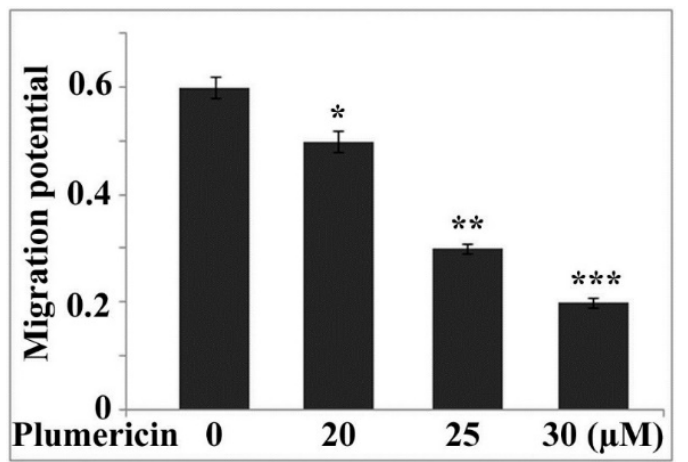

Figure 3: Effect of plumericin treatment of Hep $3 \mathrm{~B}$ cells. The cells, after incubation with 20, 25 and $30 \mu \mathrm{M}$ doses of plumericin, were subjected to Transwell invasion assay. Quantitative analysis of Transwell invasion assay showed that plumericin treatment significantly suppressed liver cancer cell invasion; ${ }^{*} p<0.05,{ }^{* *} p<0.02$ and ${ }^{* * *} p<0.02$ vs. control cells. Images captured at a magnification of $\times 100$

\section{Plumericin caused G2/M phase cell cycle arrest in Hep 3B cells}

The effect of plumericin on cell cycle in Hep 3B cells was studied at doses of 20,25 and $30 \mu \mathrm{M}$. Compared to control, the proportion of Hep 3B cells in G2/M phase of cell cycle was increased significantly at 20,25 and $30 \mu \mathrm{M}$ (Figure 4). However, the proportion of cells in S phase of cell cycle was subsequently decreased. In G2/M phase, the percentages of Hep 3B cells were $42.21,54.89$ and 59.75 on treatment with 20,25 and $30 \mu \mathrm{M}$ plumericin, respectively, for $72 \mathrm{~h}$, while the percentages of cells in S phase were $16.56,12.36$ and 8.71 , respectively on treatment with 20,25 and $30 \mu \mathrm{M}$ doses of plumericin. In G1 phase, there were $38.86,31.12$ and $30.63 \%$ of cells due to treatment with plumericin at doses of 20,25 and $30 \mu \mathrm{M}$, respectively. These results are shown in Figure 4.

\section{Plumericin treatment led to inhibition of COX-2 and VEGF expressions in Hep 3B cells}

After $72 \mathrm{~h}$ of incubation with $5,10,15,20,25$ and $30 \mu \mathrm{M}$ plumericin, the Hep $3 \mathrm{~B}$ cells were examined for expressions of COX-2 and VEGF mRNAs using RT-PCR analysis. The results showed that plumericin led to significant and concentration-dependent decreases in the expressions of COX-2 and VEGF mRNAs, relative to the control group (Figure 5). The downregulations of COX-2 and VEGF expressions were significant as from $10 \mu \mathrm{M}$ plumericin at $72 \mathrm{~h}$ (Figure 5).
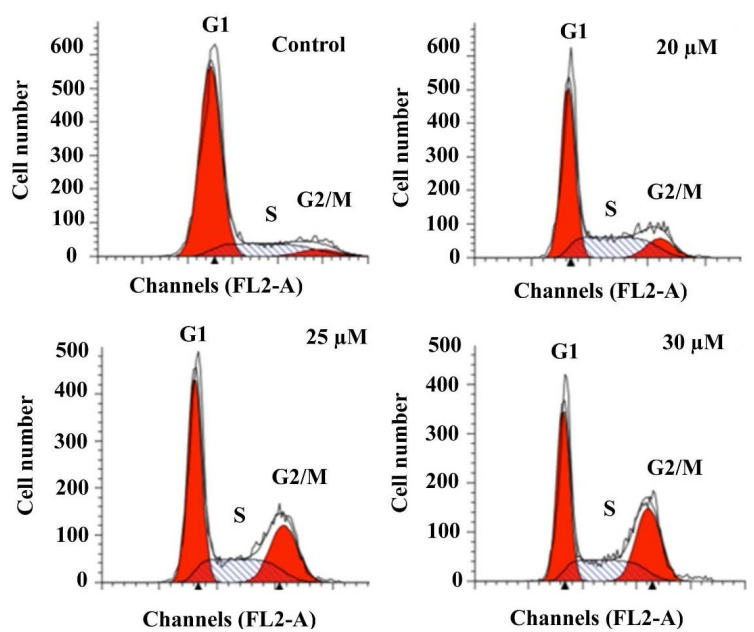

Figure 4: Effect of plumericin on cell cycle arrest in Hep 3B cells. Following incubation with 20, 25 and 30 $\mu \mathrm{M}$ plumericin for $72 \mathrm{~h}$, the cells were washed, fixed, stained with propidium iodide, and examined for DNA content using flow cytometry

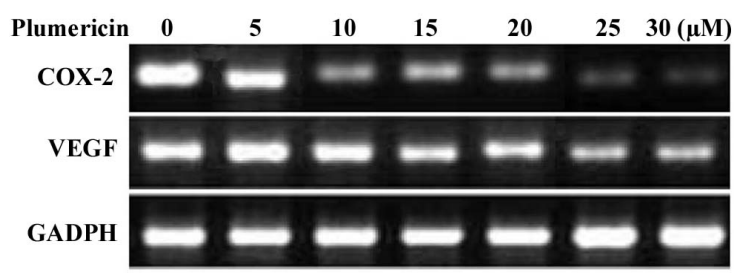

Figure 5: Plumericin reduced expressions of COX-2 and VEGF mRNA in Hep 3B cells. The cells were incubated for $72 \mathrm{~h}$ with plumericin and then subjected to RT-PCR analysis for expressions of COX-2 and VEGF mRNA

\section{Plumericin inhibited liver cancer growth in vivo}

Tumor weight was significantly lower in the plumericin-treated groups than in the control animals. However, tumor weight in animals treated with $30 \mathrm{mg} / \mathrm{kg}$ of plumericin was lower than that of $25 \mathrm{mg} / \mathrm{kg}$ treatment group. The tumor weights in control, untreated, $25 \mathrm{mg} / \mathrm{kg}$ plumericin treatment and $30 \mathrm{mg} / \mathrm{kg}$ plumericin treatment groups were $0,2.8,1.2$ and $0.4 \mathrm{~g}$, respectively.

\section{DISCUSSION}

The present study investigated the effect of plumericin on cell proliferation, invasion potential, expression of COX-2 and VEGF expression in liver cancer cells. Plumericin inhibited proliferation, induced apoptosis, suppressed invasion and downregulated the expressions of COX-2 and VEGF in liver cancer cells. Moreover, 
plumericin inhibited tumor growth in mice model of liver cancer.

In tumor tissues, the rate of cell proliferation is exceptionally high, when compared to normal tissues. In the current study, plumericin caused reduction in the proliferation of Hep $3 \mathrm{~B}$ and Hep G2 liver cancer cells. The inhibition of liver cancer growth by plumericin provided the basis for investigation of the mechanism involved in its action. Apoptosis is a very important and highly regulated biological process involved in the removal of unwanted cells from the body tissues. Abnormalities in the apoptotic process have been implicated in the etiology of cancer $[20,21]$.

In the current study, flow cytometry showed that plumericin treatment markedly induced apoptosis in Hep 3B cells. Cell cycle constitutes a series of ordered steps each of which is regulated by checkpoints [22]. These checkpoints regulate cell cycle progression through extracellular signal detection, protein synthesis and DNA integrity [22]. Disorder in cell cycle is the leading cause of uncontrolled cell division. In the present study, flow cytometric analysis showed that plumericin treatment of Hep 3B cells arrested cell cycle in G2/M phase. This finding suggests that plumericin inhibits liver cancer cell growth by arresting cell cycle progression. In various types of tissues, the inducible enzyme, COX-2 is not expressed typically [23].

However, stimulation of various cells such as endothelial cells, monocytes, macrophages, vascular smooth muscle cells and fibroblasts by pro-inflammatory cytokines leads to the expression of COX-2 [23]. Up-regulation of COX-2 expression is associated with the secretion of inflammatory cytokines which enhance inflammation and tissue damage [23]. Moreover, COX-2 overexpression promotes proliferation of cells and disrupts equilibrium between apoptosis and cell proliferation [24]. In the current study, plumericin treatment of liver cancer cells inhibited the expression of COX-2.

The microenvironment of tumor cells consists of growth factors and chemotactic agents which promote tumorigenesis by increasing cell proliferation, migration and invasion [25]. The present study showed that plumericin exposure markedly reduced the invasion potential of Hep 3B cells. Studies have revealed that growth of liver cancer is reduced by some chemotherapeutic agents through targeting of the expressions of inflammatory cytokines [26,27]. Results from the present study revealed that plumericin treatment markedly inhibited tumor growth in vivo in a mice model, relative to untreated control mice.

\section{CONCLUSION}

The results obtained in this investigation indicate that plumericin efficiently suppresses liver cancer cell growth in vitro and in vivo through a mechanism involving the down-regulation of the expressions of COX-2 and VEGF. Thus, plumericin may be suitable for the clinical treatment of liver cancer.

\section{DECLARATIONS}

\section{Acknowledgement}

The authors appreciate the financial support received from Jiaxing Science and Technology Bureau (no. 2018AD32101).

\section{Conflict of interest}

The authors declare that no conflict of interest is associated with this study.

\section{Authors' contribution}

We declare that this work was done by the authors named in this article and all liabilities pertaining to claims relating to the content of this article will be borne by the authors. Liang $\mathrm{Li}$ designed the study and compiled the data. Jie Min, Lili Cao and Jun Zhou carried out the experiments and performed the literature study. All the authors wrote and approved the article for publication.

\section{REFERENCES}

1. Ma S, Chan KW, Guan XY. In search of liver cancer stem cells. Stem Cell Rev 2008; 4: 179192.

2. Tomuleasa $C$, Soritau $O$, Rus Ciuca D, Pop Teodora, Todea D, Mosteanu O, Pintea B, Foris V, Susman $S$, Kacsó $G$, Irimie $A$. Isolation and characterization of hepatic cancer cells with stem like properties from hepatocellular carcinoma. J Gastrointestin Liver Dis 2010; 19: 6167.

3. Ricci Vitiani L, Lombardi DG, Pilozzi E, Biffoni M, Todaro $M$, Peschle $C$, De Maria R. Identification and expansion of human colon cancer initiating cells. Nature 2007; 445: 111115.

4. Lee TK, Castilho A, Ma S, Ng IO. Liver cancer stem cells: implications for a new therapeutic target. Liver Int 2009; 29: 955965.

5. Guicheng $H$, Xiaocheng $C$, Meng $H$, Xifeng $S$, Youhua $W$, Xiaohong A. Casticin inhibits self-renewal of liver cancer 
stem cells from the MHCC97 cell line. Oncology Lett 2014; 7: 2023-2028.

6. Darvesh AS, Aggarwal BB, Bishayee A. Curcumin and liver cancer: a review. Curr Pharm Biotechnol 2012; 13. 218228

7. Li W, Gao Z, Yang C, Li J, Li L, Lv R, Liu Z. The estimation of prevalence, incidence, and residual risk of transfusion transmitted human hepatitis $B$ infection from blood donated at the Anhui blood center, China, from 2009 to 2011. PloS One 2013; 8: e73472.

8. Su $Y$, Norris JL, Zang C, Peng Z, Wang N. Incidence of hepatitis $C$ virus infection in patients on hemodialysis: a systematic review and meta-analysis. Hemodial Int 2013; 17: 532541.

9. Chen WQ, Zheng RS, Zhang SW. Liver cancer incidence and mortality in China, 2009. Chin J Cancer 2013; 32: 162169.

10. Pharmacopoeia Commission of People's Republic of China: Pharmacopoeia of the Peoples Republic of China. Vol 1. China Chemical Industry Press, Beijing, 2010 (In Chinese).

11. Ye Q, Zhang QY, Zheng CJ, Wang Y, Qin LP. Casticin, a flavonoid isolated from Vitex rotundifolia, inhibits prolactin release in vivo and in vitro. Acta Pharmacol Sin 2010; 31: 15641568.

12. Shen JK, Du HP, Yang M, Wang YG, Jin J. Casticin induces leukemic cell death through apoptosis and mitotic catastrophe. Ann Hematol 2009; 88: 743752.

13. Cheng JH, Chang G, Wu WY. A controlled clinical study between hepatic arterial infusion with embolized curcuma aromatic oil and chemical drugs in treating primary liver cancer. Zhongguo Zhong Xi Yi Jie He Za Zhi 2001; 21: 165167 (In Chinese).

14. Wang WX, Li TX, Ma H. Tumoral cytotoxic and antioxidative phenylpropanoid glycosides in Smilax riparia A. DC. J Ethnopharmacol 2013; 149: 527532.

15. Liang QL, Dai CC, Jiang JH, Tang YP, Duan JA. A new cytotoxic casbane diterpene from Euphorbia pekinensis. Fitoterapia 2009; 80: 514516.
16. Fang R, Houghton PJ, Hylands PJ. Cytotoxic effects of compounds from Iris tectorum on human cancer cell lines. J Ethnopharmacol 2008; 118: 257263.

17. Duan JA, Wang L, Qian S, Su S, Tang Y. A new cytotoxic prenylated dihydrobenzofuran derivative and other chemical constituents from the rhizomes of Atractylodes lancea DC. Arch Pharm Res 2008; 31: 965969.

18. Lin H, Liu J, Zhang Y. Developments in cancer prevention and treatment using traditional Chinese medicine. Front Med 2011; 5: 127133.

19. Bauer JS, Schreiner CL, Giancotti FG, Ruoslahti E, Juliano RL. Motility of fibronectin receptor deficient cells on fibronectin and vitronectin: collaborative interactions among integrins. J Cell Biol 1992; 116: 477487.

20. Chen Y, Bieber MM, Teng NN. Hedgehog signaling regulates drug sensitivity by targeting $A B C$ transporters $A B C B 1$ and $A B C G 2$ in epithelial ovarian cancer. Mol Carcinog 2014; 53: 625634.

21. Zhang $P$, Jia R, Ying L, Liu B, Qian G, Fan X, Ge S. WWOX mediated apoptosis in A549 cells mainly involves the mitochondrial pathway. Mol Med Rep 2012; 6: 121124

22. Park M-T, Lee S-J. Cell cycle and cancer. J Biochem Mol Biol 2003; 36: 60-65.

23. Dubois RN, Abramson SB, Crofford L, Gupta RA, Simon LS, Van De Putte LB, Lipsky PE. Cyclooxygenase in biology and disease. FASEB J 1998; 12: 10631073.

24. Markosyan $N$, Chen EP, Evans RA, Ndong $V$, Vonderheide RH, Smyth EM. Mammary carcinoma cell derived cyclooxygenase 2 suppresses tumor immune surveillance by enhancing intratumoral immune checkpoint activity. Breast Cancer Res 2013; 15: R75.

25. Fidler IJ. The pathogenesis of cancer metastasis: The 'seed and soil' hypothesis revisited. Nat Rev Cancer 3: 453-458, 2003.

26. Pang R, Tse E, Poon RT. Molecular pathways in hepatocellular carcinoma. Cancer Lett 2006; 240: 157 169.

27. Wong CM, Ng IO. Molecular pathogenesis of hepatocellular carcinoma. Liver Int 2008; 28: 160174. 